\title{
The Impact of Business Scale of "Shadow Banking" on Credit Risk of Commercial Banks --Take Ten Domestic Listed Commercial Banks as Examples
}

\author{
Sijia Wen ${ }^{1}$, Jishan $\mathrm{Ma}^{1}$, Yawen Pan ${ }^{1}$, Yuan $\mathrm{Qi}^{1} \&$ Ruizhi Xiong ${ }^{1}$ \\ ${ }^{1}$ Finance Department of International Business School, Jinan University, Zhuhai, China \\ Correspondence: Jishan Ma, Jinan University, No.206, Qianshan Road, Xiangzhou District, Zhuhai, China. Tel: \\ 86-158-2058-0342. E-mail: 2487948059@qq.com
}

Received: March 2, 2017

Accepted: March 30, 2017

Online Published: April 15, 2017

doi:10.5539/ijef.v9n5p94

URL: https://doi.org/10.5539/ijef.v9n5p94

\begin{abstract}
In this article, according to search for the definition of shadow banking, we can make sure the business kinds of "shadow banking", discuss the influence of business in "shadow banking" on credit risk of commercial banks, and study the elements which may increase the credit risk of commercial banks by using the semi-annual panel data during 2011-2016 of 10 listed banks. Then we can come to some primary conclusions: The credit risk of commercial banks is related to the shadow banking business. All the survival scale increment of financial products increasing, the size of entrusted loans increasing in increment, and the increasing in the size of guarantee commitments will increase the credit risk of commercial banks. There is no obvious relationship between trust loan business and bank credit risk. Our study is of great significance for the government to supervise the off-balance-sheet business of commercial banks. At the same time, it also fills the vacancy of domestic commercial banking "shadow banking" business empirical research.
\end{abstract}

Keywords: commercial banks, the business scale of "shadow banking", credit risk

\section{Introduction}

\subsection{Background and Significance}

Because of the global financial crisis in 2008 , people began to realize that there is a complicated and huge system of "shadow banking" hiding in traditional system of commercial banks. Until the past few years, "shadow banking" in China has expanded rapidly. Recently, the mainland economy slowdowns, under the circumstance of suppression for whole credit, the non-bank credit can make private enterprises get more credit resources, its importance increases greatly; but at the same time, it also take challenges for national financial stability. Especially the money shortage in 2013 which had arisen the liquidity risk, it pushed the shadow banking to the cusp of public opinion.

All the command and control regulatory system will always encourage people to get rid of the restraints of these rules, resulting in regulatory arbitrage. The motivation of the banking industry to engage in regulatory arbitrage is the pursuit of high profits, which is closely related to the bankers' risk incentive policies: although the banks have medium-term or long-term planning, the assessments for the management are linked to short-term operating results, leading to short-term banker's business strategy, inspiring the banks to pursue high-risk strategy.

In addition, the asymmetry of information between regulators and supervisors also enables regulatory arbitrage activities to continue, and in this process, shadow banking play a key important role. Due to the opaque information and the high cost of regulation, regulatory arbitrage is the norm in the banks industry. Commercial bank regulatory arbitrage mostly occurs in the blind areas of the regulatory system to carry out normal business activities, which hide in the complex and diverse normal business and trading activities and do not touch the "red line" of the regulatory, called the gray area.

At present, the study scope of experts and scholars mostly is from the macro perspective, that is, the overall concept and impact of the shadow banking system; and we hope to start from the internal banking business of commercial banks, from the micro-perspective to study its operational mechanism and risk transmission model in-depth, which will unveil the fact of shadow banking, promote social understanding for shadow banking, 
improve the regulatory system for shadow banking and at the same time promote the cooperation between shadow banks and the traditional commercial banks, and greatness from trivial, in order to jointly promote China's economic development, we should pay effort to create a financial market of sustainable development.

\subsection{Literature Review}

\subsubsection{Some Researches on Shadow Banking System at Home and Abroad}

Internationally, the concept of "shadow banking" was born in 2007 after the outbreak of the US sub-prime mortgage crisis. McCulley (2007) the director of American Pacific Investment, the first people who defined it as "all non-bank investment channels, investment instruments, and structured products with leveraged investments that correspond to the traditional, regulated commercial banking system." Among them, these non-bank investment institutions mainly refers to money market funds, private equity funds and structured investment. Former Treasury Secretary Geithne (2010) called the shadow banking system the "parallel banking system", which he thinks has developed into a financing system that parallels with traditional commercial banking system. Some American economists, such as Pozsar (2010), argues that the lack of regulatory in shadow banking development will impact on traditional commercial banks because shadow banks reduce the liquidity of commercial banks and squeeze their profit margins. He argues that among the shadow banking system is interconnected with some intermediary chains that provide Innovative investment technology and asset securitization, packaging long-term, high-risk, opaque assets as short-term debt of non-risk in surface so as to snatch funds, as well as compete against the traditional credit market. Currently, it's mostly considered the definition of shadow banking by Board (2011) study that is more formalized : the shadow banking system is a system that provides credit intermediary for institutions and activities outside the traditional commercial banking system, which are mainly engaged in the activities that accept financing similar to deposit characteristics, implement a term transition or liquidity, make the transfer of credit risk, and use the lever directly or indirectly. Its sources of financing mainly include debit and credit of securities, repurchase and securitization.

In conclusion, the shadow banking system of developed countries in Europe and the United States is dominated by non-bank financial institutions, mainly with wholesale financing, and by the means of the innovation of financial products such as asset securitization; it is a product of excess supply of financial services. There is a competitive relationship between shadow banking system and traditional banking system. In contrast, China's shadow banking is mainly based on leading by commercial banks and retail financing. Because of the immaturity of derivative financial products, the China shadow banks are more market-oriented innovations that aimed at regulatory arbitrage. They are the products of financial repression. In a word, China shadow banking system and the traditional bank is the complementary relationship.

\subsubsection{A Survey of Shadow Banking Business in Chinese Commercial Banks}

For the reason that the commercial banks occupy a dominant position in our country's shadow banking system, so we decide to put the focus of the study on the principle part of China shadow banking-- the "shadow business" of commercial banks. According to a lot of literature researches, we divided the shadow businesses of commercial banks into four types: financial products, entrusted loans, trust loans and acceptances.

1) Financial products

Banking financial products, according to standard explanation, is a fund investment and management plan developed and marketed for specific target segments based on analyzing and searching for potential target customers by commercial banks. In the recent years, the business scale of financial products has been increasing continuously and rapidly. By the end of 2015, a total of 426 banking financial institutions survived financial products; the number of financial products is 60879 , while financial capital balance is 23.50 trillion yuan. Compared with the end of 2014, increased 8.4 trillion yuan, an increase of 56.46\%.

We call this operation model as "capital pool - asset pool" model. Most of the term of financial products is short-term or ultra-short-term, and its corresponding investment portfolio includes not only the central bank bills, repurchase, corporate ultra-short-term financing and other short-term assets, including treasury bonds, corporate bonds, asset management plans, trust benefits rights and other long-term assets (Guo, 2016). Banks in response to structure of asset return period and the payback period that is not synchronized, only have to put all the old and new financial products into a "pool of funds", through the rolling sale of financial products to match the deadline. And this kind of "new payment for old" gives the bank a great risk.

\section{2) Entrusted loans}

Entrusted loans refer to funds provided by clients, such as government departments, enterprises, institutions and individuals, and the loans that commercial banks (trustees) shall issue, supervise and assist in recovery according 
to loan objects, purposes, amount, currency, term and interest rate as determined for different principals. Entrusted loans enrich the financial products, expand the financing channels, and the bank access to the intermediary business income, easing the pressure of deposit and lending, but at the same time, entrusted loans as the bank's off-balance sheet business, funding sources are complex; forms of put-in are various, likely to cause certain loans risk.

3) Trust loans

Commercial banks use financial products to finance, cooperate with trust companies, securities companies, insurance companies and other non-bank financial institutions, such financial products is the financial products that combined with the channel of commercial banking products and the investment channel of non-bank financial institutions. But the operating means of shadow banks only make use of these institutions as a channel, then move the assets outside the table, so as to expand the scale of credit. This is a single channel model of the shadow banking business; among them, the most typical example is the trust loans in the cooperation of banks and trust companies.

We can divide the cooperation into two modes:

The first type, the mode of financial. That is to say, the trust company acts as the third party of "cross-bridge", in their own name to establish a trust plan to direct financing for company which lack of funds, and then the proceeds of the trust program transfer to the bank's financial products, thus when bank completing the financing of enterprises, trust company have also attained a channel fee. Of course, this is only the simplest mode we have explored. In practice, a bank may find other banks as cross-bridge channels to avoid regulation.

Second, the investment model. That is, the bank to trust credit or credit plan for direct investment, but in 2010 the China Banking Regulatory Commission to increase inspection efforts, such funds have been transferred to the table, so this approach is more difficult to avoid regulation.

\section{4) Bank acceptances}

A commercial bank acceptance is a commercial draft drawn by a bank that promises to pay at maturity. Because of its unique characteristics and advantages, it has become one of the important ways of settlement between enterprises. It plays a positive role in strengthening social capital financing, supporting enterprise purchase and sales activities, and enhancing the bank's profitability.

\subsubsection{A Study on the Impact of "Shadow Banking" on the Risk of Commercial Banks}

By reading lots of literature, we found that domestic and foreign scholars are still at the macro level in the empirical study of the shadow banking system as well as the measurement of the relationship of systematic risk in banking. In the following, we will open a new path, to explore the relationship between microscopic "shadow banking" business and credit risk of commercial banks.

Instefjord (2005) used a simple financial distress cost model for empirical research to examine whether credit derivatives, which are "shadow banking" financial innovations, would make banks expose credit risk. The author argues that although credit derivatives can share some of the risks, if the credit derivatives are used by banks to speculate, it is likely to shake the banking system, making it very unstable.

Calmès, and Théoret (2011) argued that the off-balance sheet activities of commercial banks are an important branch of the shadow banking system. They use the financial data outside the Canadian commercial bank's balance sheet to do the empirical analysis, and come to a conclusion that the commercial bank's "shadow business" activities increase the fluctuation of the banks' operating income.

Mao and Wan (2012) make use of the macro economic conditions indicators (20\%), financial conditions indicators (30\%), and bank operating indicators (50\%) to measure the stability of China's banking industry, and they use scale, money supply growth rate, GDP and money supply ratio, the nominal interest rate of the shadow banking as the explanatory variables, then the result shows that the relationship between the scale of China's shadow banking system and the stability of the banking system is a " $U$ " -type; the threshold is 6.07. When the shadow banking scale is lower than 6.07 trillion yuan, the development and growth of shadow banks will help the stability of the banking system; on the contrary, the scale of the shadow banking aggravates the instability of the banking system.

Gao (2013) thinks that the unobserved credit, off-balance sheet business of commercial banks, non-bank financial institutions is a Chinese-style shadow banking. By measuring their scale during 1992-2011 and doing empirical analysis according to related models, the result shows that the shadow banking scale has a positive effect on the systematic risk of commercial banks in China. The increasing of shadow banking scale will 
exacerbate the systemic risk of commercial banks in China.

\section{Risk Transmission Mechanism of "Shadow Banking" Business}

\subsection{Information Asymmetry}

Compared with the traditional banks, the product structure of the shadow banking is more complicated, and a lot of off-balance-sheet transactions make the business activities have a strong concealment, then information disclosure system is not well implemented; resulting in the asymmetry of the information between buyers and sellers, it must lead to accumulate much investment risk. Asymmetric information, that is, there are many opaque blind spots of information in the shadow banking business which make investors in the choice of financial products obtain inadequate information, and ultimately lead asset to damage. The adverse selection and moral hazard are the important reasons for banking systemic risk.

\subsection{Term Mismatch}

Term mismatch is mainly elaborated the problem that the commercial banks use short-term funds in long-term. The greater the number of funds that a bank needs, the more pressing the time; the shorter the duration of financial products, in contrast the income will be higher, or even it would occur the phenomenon of yield period upside down. In order to obtain a higher rate of return, long-term financing projects and long-term assets have become the ideal investment choice for banks. The short-term financial products invest greatly in long-term assets and that is why term mismatch occurs. Such conducts will cause liquidity risk, credit risk of commercial banks and so on, and even affect the stability of the financial system.

\subsection{High Leverage}

The high leverage in shadow banking business of commercial banks is mainly from the traditional commercial bank's off-balance-sheet assets. The assets in-the- table of the commercial banks are often subject to the regulatory authorities in the capital adequacy ratio, deposit reserve and other aspects of the regulation, so the leverage of traditional business can be controlled within a certain range. However, in order to pursue the excess profits brought by the risk premium, the traditional commercial banks will be transform the table of assets into off-balance-sheet assets, through the shadow banking business, expand its leverage, which is able to avoid financial regulation to a certain extent, so as to bring higher returns for banks themselves. For example, a commercial bank would pack some of the less liquid assets into asset-backed securities (ABS) in the form of asset securitization, and then make a CDO to amplify its leverage and expand its business scale, aim to obtain more income.

\subsection{Defects of Product Design}

First of all, China's commercial banks consider it simple in product design, and not yet weight various related factors from different aspects. Compared with the study of the customers, at present most commercial banks divide their customers simply based on the amount of money and age of the customer, while ignoring the individual differences within the investors. It is ensured that product design does not take into account the individuality of investors. Secondly, there is a problem of low transparency in the product design of commercial banks in China. Shadow banking repeatedly nested use through securitization and derivatives and other structural design and leverage, making the shadow banks are over-packaged, so that investors can't obtain those original information and risks of derivative products corresponding to the basic products, what they can do is only depend on rating agencies, and rating agencies' irresponsible rating will make shadow banking ignore risks further.

\section{Empirical Analysis Based on Panel Regression}

Generally speaking, common influencing factors analysis researching individual difference mostly use Linear regression model based on cross sectional data. However, this method ignores the special effects among individuals, the individual time series data is able to supplement this. Panel data, as a data type that can make up for the defects of time series data and cross section data to some extent, is widely used in economic research. Owing to the panel data which contain information of cross section and time series, the panel data is able to analyze generality and individuality of cross section. Using panel data to establish econometric model will make the model more accurate and comprehensive. Therefore, this paper uses econometric tools based on Panel Data to analysis the factors of commercial bank credit risk.

The explained variable is set as probability of default, which we shall denote by KMV, calculated by the KMV model. we finally chose the scale of financial products (FPRO), the income from principal-agent business (AGEN), the income from custody and entrusted service (COLLO), the income from guarantee business (GUAR) 
as explanatory variables, total asset (CAP) as control variable. The model (Han, 2009) is set as follows:

$$
\begin{gathered}
K M V_{i t}=\alpha_{i}+\beta_{1} F P R O_{i t}+\beta_{2} A G E N_{i t}+\beta_{3} C O L L O_{i t}+\beta_{4} G U A R_{i t}+\beta_{5} C A P_{i t}+\varepsilon_{i t} \\
i=1,2, \cdots, 10 \quad t=1,2, \cdots, 11
\end{gathered}
$$

$\alpha_{i}$ is set as individual drift term, which reflect the influence of individual special effects on the model. $\beta$ is set as parameters of explanatory variables. The meaning of variables' subscripts is that the value of the $i$ th individual at time $t . \varepsilon_{i t}$ is set as the stochastic error term, which follows zero mean valued and homo-scedastcity normal distribution.

\subsection{Choosing Data and Variable}

In this paper, we study the 2011-2016 Semi-annual data of 10 commercial banks listed in Shanghai Stock Exchange and Shenzhen Stock Exchange (ICBC, Agricultural Bank of China, CCB, CEB, China Merchants Bank, China Merchants Bank, Shanghai Pudong Development Bank, China Citic Bank, CIB, CMSB). The data is from the annual reports of bank, the semiannual reports of bank, and wind database.

\subsubsection{Selection and Calculation of the Explanatory Variable}

The explained variable is set as probability of default, which we shall denote by KMV, calculated by the KMV model. We can see the specific calculation process as follows:

1) Calculate the asset value of the company

According to Merton model, we can compare the stock market value with the value of the company's assets. Therefore, we get the formula calculating the value of company assets.

$$
E=V_{A} N\left(d_{1}\right)-D e^{-r T} N\left(d_{2}\right)=f\left(V_{A}, D, r, T, \partial_{A}\right)
$$

$E$ is set as company's equity value, it reflects the prices of company's shares. $V_{A}$ is set as the value of the assets of the company, it is an unknown parameter. $D$ is set as the value of the corporate debt. $r$ is set as risk-free interest rate. $T$ is set as debt maturity. $\partial_{A}$ is set as the volatility of the value of the company' assets, it is an unknown parameter. $N$ is set as cumulative normal distribution function. Then we get formulas of $d_{l}$ and $d_{2}$.

$$
\begin{gathered}
d_{1}=\frac{\ln \left(V_{A} / D\right)+\left(r+\partial_{A}\right) / 2 T}{\partial_{A} \sqrt{T}} \\
d_{2}=d_{1}-\partial_{A} \sqrt{T}
\end{gathered}
$$

According to ITO lemma:

$$
\partial_{E}=V_{A} / E \times N\left(d_{1}\right) \partial_{A}
$$

$\partial_{E}$ is set as the equity value volatility. we get $V_{A}$ and $\partial_{\mathrm{A}}$ calculated from the formula.

2) Calculate the expected asset value of the company, calculate the optimal default-triggering level $(D P)$ and distance to default $(D D)$

According to previous option pricing theory, when the value of the assets of the company is smaller than or close to total debts, the company may default. Based on calculation, KMV company find that at some point the value of the assets of the company is between short-term liabilities and total debt, the company will default. That point is called the optimal default-triggering level $(D P)$. DP is defined as the following formula:

$$
D P=S T D+0.35 * L T D
$$

$D D$ refers to the distance between Expected value of asset value's probability distribution and the optimal default-triggering level, refers to the possibility of default. $D D$ is defined as the following formula:

$$
D D=\frac{E\left(V_{T}\right)-D P}{E\left(V_{T}\right) \partial_{A}}
$$

$E\left(V_{T}\right)$ refers to the average value of asset value at time $T$, if the value of the assets of the company follows geometric Brownian motion, and the value of the assets of the company is $V_{A}$, the value of the assets of the company at time $T\left(V_{T}\right)$ will be defined as the following formula:

$$
V_{T}=V_{A}\left[\exp \left(\mu-\partial_{A}^{2} / 2\right) T+\partial_{A} \sqrt{T \varepsilon}\right]
$$

$\mu$ is set as the expected growth rate of the asset value. $\varepsilon$ is set as standard normal distribution variable. For the both sides we take expectations.

$$
E\left(V_{T}\right)=V_{A} e^{\mu T}
$$

According to the option theory framework, the debt is due and cannot be repaid should count as a default. We get 
a formula as follow:

$$
P=P_{T}\left(V_{T} \leq D\right)
$$

According to the frame of Option Theory, it is regarded as default only when maturing debts aren't able to be paid, using a mathematical formula expressing as follows:

$$
P=P_{T}\left(V_{T} \leq D\right)
$$

In the formula, default possibility is expressed by $\mathrm{P}$, total amount of debts which should be fulfilled on maturity date is expressed by $\mathrm{D}$, and makes an assumption that corporate asset value follows logarithmic normal distribution, so simultaneous the two formulas and we can get:

$$
\begin{aligned}
P & =P_{T}\left(\varepsilon \leq \frac{\ln \left(D / V_{A}\right)-\left(\mu-\frac{\partial_{A}^{2}}{2}\right) T}{\partial_{A} \sqrt{T}}\right) \\
& =N(-D D) \\
& =1-N(D D)
\end{aligned}
$$

The third step: Expected Default Frequency(EDF), determine the mapping relationship between default rate and default distance. It is normal to use theoretical default rate, namely:

$$
E D F=N(-D D)=1-N(D D)
$$

In this formula, the method of parameter setting is as follows:

1) The parameter estimation of corporate equity value(E)

Generally, we can consider the market value of the shares of listed companies as corporate equity value, because the price change of companies' shares is closely linked with the market value change of corporate equity, and as the free flow of exchange asset, the price change of shares reflects market evaluation of companies. According to the national research, use the following formula to count the corporate equity value:

corporate equity value $(E)=$ tradable shares $\times$ closing price + non-tradable shares $\times$ net asset value per share

2) The parameter estimation of equity value volatility $\left(\partial_{E}\right)$

In this paper, we use the historical volatility to estimate.

3) The setting method of the expected growth rate of asset value $(\mu)$

In order to research conveniently, we assume the expected growth rate of asset value is 0 .

4) The setting of the book value of corporate debt $(D)$ and default trigger point (DP)

The default face value of listed companies is the total of long-term liabilities and current liabilities in the information disclosure. On the setting of default trigger point(DP), according to the national research, we think: DP=STD+0.35LTD.

5) The setting of risk-free interest rate $(r)$ and debt maturity $(T)$

It is more consistent with the setting of risk-free interest rate and debt maturity in the national research. Generally, the setting of risk-free interest rate is set as One-year Keeps deposit interest rate published by People's Bank of China, and debt maturity is set as one year.

The KMV results are as follows:

Table 1. The KMV results for the first half of 2016

\begin{tabular}{lcc}
\hline Name & Default distance & Probability of default $(\%)$ \\
\hline BOC & 1.112 & 0.133 \\
ABOC & 1.119 & 0.132 \\
ICBC & 1.133 & 0.092 \\
CCB & 1.021 & 0.154 \\
CMB & 1.224 & 0.110 \\
CEB & 0.964 & 0.168 \\
CIB & 1.170 & 0.121 \\
CHINA CITIC BANK & 1.032 & 0.151 \\
CPDB & 1.249 & 0.110 \\
CMBC & 1.058 & 0.145 \\
\hline
\end{tabular}




\subsubsection{Select the Explanatory Variables.}

1) Existent scale of financial products

We record the existent scale of financial products as FPRO. The data of this variable after 2013 (including 2013) has been disclosed by the given banks in the annual reports. Nevertheless, we cannot get the precise data before 2013 because of the obscure information disclosure. Therefore, we obtain that part of missing data by regression estimation.

\section{2) Agency business income}

We record the agency business income as AGEN. The data of this variable is obtained from the wind database. The above have mentioned that the entrusted loan business income has been included in the agent commissioned details of non-interest income in the income statements, in that we can approximate the agency business income as the scale of the entrusted loans.

\section{3) Managed and entrusted business income}

We name the managed and entrusted business income as COLLO. The data of this variable is obtained from the wind database. As mentioned above, the trust loan business income is included in the trust and fiduciary business details of the non-interest income in the income statements, so we will approximate the managed and entrusted business income as the size of the trust loans.

\section{4) Guarantee undertaking business income}

We name the guarantee undertaking business income as GUAR. The data of this variable is obtained from the wind database. The above has mentioned that the acceptance bill income is included in the guarantee undertaking business income details of the non-interest income in the income statements, so we can approximate the income of the undertaking business as the scale of acceptance bills.

\subsubsection{Select Control Variable}

Because of that analyzes the present literature and pushes on the research, we also need to introduce several control variables in our model. As a result, we select the size of the total assets, denoted as CAP: in general, the larger banks, the greater risk controlling ability.

\subsection{Manage the Sample Data}

\subsubsection{Fill Up the Missing Value}

Looking up the wind database, due to the size of the financial product data before 2013 is not disclosed or disclosed by the majority of banks, in this paper, because the sample size is too small, it is not appropriate to utilize the traditional method to deal with missing values. Using the known data to draw the scatter plot, we find that there is a clear trend. Hence, we use the exponential regression model to estimate the missing values:

Table 2. Regression consequence of financial products

\begin{tabular}{lcccc}
\hline Name & Number of missing value & $\mathbf{R}^{\mathbf{2}}$ & F statistics & Sig. \\
\hline BOC & 5 & 0.506 & 4.009 & 0.113 \\
ABOC & 4 & 0.925 & 61.53 & 0.001 \\
ICBC & 7 & 0.867 & 13.067 & 0.069 \\
CEB & 1 & 0.979 & 379.135 & 0.000 \\
CMBC & 2 & 0.972 & 242.721 & 0.000 \\
CIB & 5 & 0.915 & 43.110 & 0.003 \\
CHINA CITIC BANK & 3 & 0.942 & 97.706 & 0.000 \\
SPDB & 5 & 0.946 & 69.515 & 0.001 \\
China Minsheng Banking Corp & 3 & 0.913 & 63.061 & 0.000 \\
\hline
\end{tabular}

The results of the analysis show that, except the regression effect the Bank of China and industrial and Commercial Bank of China is not ideal, the other 7 banks reject the original hypothesis $\mathrm{F}$ test at the level of $0.5 \%$, and except the Bank of China, the $\mathrm{R}^{2}$ is greater than 0.85 , most of the bank's $\mathrm{R}^{2}$ value is more than 0.9. It shows that the fitting degree of regression curve is very high, and the relationship between time and financial products is very significant. Therefore, it is feasible to use exponential regression to estimate missing data.

\subsubsection{Deal with Seasonal Smoothing}

By mapping the known data, we find that there exists obvious seasonal effect in the time series of some variables 
in a single bank. Through the analysis of the time trend diagram, we know that AGEN, COLLO, GURA these three variables are affected by seasonal factors. In order to carry out more accurate empirical analysis, we manage the seasonal smoothing, the process is as follows:

1) A simple regression of the time series is given, and the predicted value is obtained.

2) By dividing the actual value with the corresponding forecast value, the seasonal ratio of each year is obtained.

3) Average the value of the same season to get a set of seasonal index

4) The seasonal index is adjusted so that its mean is equal to 1 .

5) The actual value is divided by the seasonal index corresponding to the season, and finally get rid of seasonal data.

The sample is as follows:

\section{AGEN_ABOC}

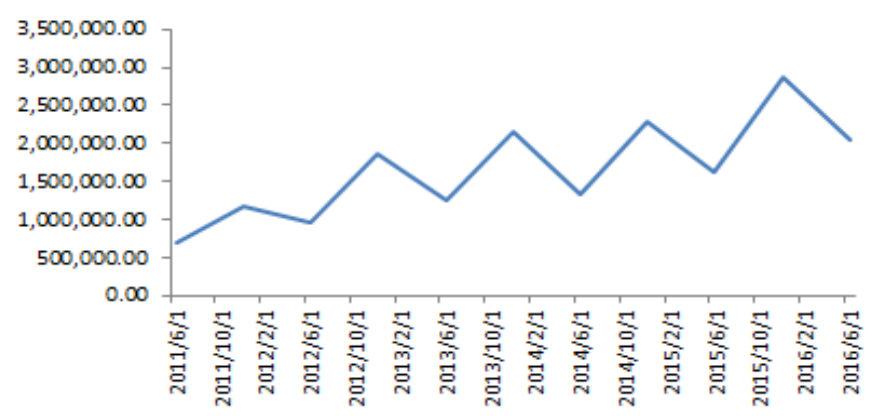

Picture 3. Time trend chart of ABOC's AGEN

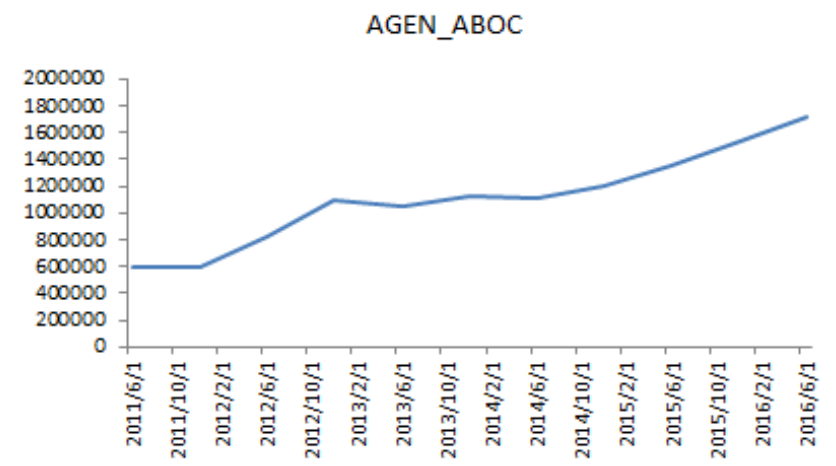

Picture 4. Time trend chart of ABOC's AGEN after seasonal treatment

\subsection{Descriptive Statistics and Stationarity Test}

Table 3 is the descriptive statistics of the sample data of the ten listed commercial banks in china. It can directly reflect the distribution characteristics of then sample data, and it is convenient for subsequent empirical study.

Table 3. Descriptive statistics of sample data

\begin{tabular}{cccccc}
\hline Variable & FPRO & AGEN & COLLO & GUAR & CAP \\
\hline Unit & Hundred million & Ten thousand & Hundred million & Hundred million & Ten thousand \\
Average & 7831.436 & 515982.3 & 23.996 & 21.251 & 852781630.17 \\
Medium & 6671.194 & 380847.3 & 17.89 & 15.545 & 458250850 \\
Maximum & 26165.98 & 2046313 & 141.35 & 91.11 & 2352432700 \\
Minimum & 711.987 & 31900 & 0.007 & 1.72 & 166212723.6 \\
Standard deviation & 5611.826 & 472404.6 & 22.366 & 18.805 & 648893075.3 \\
\hline
\end{tabular}

According to the result, the correlation coefficient between the variables is below 0.6, so the correlation is not significant. 
Table 4. Correlation coefficient between variables

\begin{tabular}{lccccc}
\hline & FPRO & AGEN & GUAR & COLLO & CAP \\
\hline FPRO & 1 & & & & \\
AGEN & 0.211 & 1 & & & \\
GUAR & 0.209 & 0.334 & 1 & 1 & 1 \\
COLLO & 0.483 & 0.054 & 0.098 & 0.174 & 1 \\
CAP & 0.565 & 0.258 & 0.463 & & \\
\hline
\end{tabular}

On this basis, this paper carries on the stability test to take the ADF test to carry on the unit root test to the above several sets of data, and the test result is shown in Table 5:

Table 5. Unit root test results

\begin{tabular}{|c|c|c|c|}
\hline Variable & Test method & Statistics & P-value \\
\hline \multirow{2}{*}{ FPRO } & $\mathrm{ADF}$ - Fisher Chi-square & 1.731 & 1.000 \\
\hline & ADF - Choi Z-stat & 7.911 & 1.000 \\
\hline \multirow{2}{*}{ AGEN } & $\mathrm{ADF}$ - Fisher Chi-square & 8.270 & 0.990 \\
\hline & ADF - Choi Z-stat & 5.001 & 1.000 \\
\hline \multirow{2}{*}{ COLLO } & $\mathrm{ADF}$ - Fisher Chi-square & 13.704 & 0.845 \\
\hline & ADF - Choi Z-stat & 2.926 & 0.998 \\
\hline \multirow{2}{*}{ GURA } & $\mathrm{ADF}$ - Fisher Chi-square & 37.960 & 0.009 \\
\hline & ADF - Choi Z-stat & -1.495 & 0.068 \\
\hline \multirow{2}{*}{ CAP } & ADF - Fisher & 2.538 & 1.000 \\
\hline & ADF - Choi Z-stat & 5.783 & 1.000 \\
\hline
\end{tabular}

According to the test results shown in Table 5, we can know that FPRO, AGEN, COLLO, CAP these three variables have unit roots, GURA reject the assumption that there is a unit root at the significance level of 5\% to, that is, the variables are stable. After that, the unit root test is performed for the first order difference sequence of the other four non-stationary variables. The results are shown in Table 6:

Table 6. Unit root test for the first order difference sequence of variables

\begin{tabular}{clcc}
\hline variable & Testing method & statistics & P-value \\
\hline \multirow{2}{*}{$\Delta$ FPRO } & ADF - Fisher Chi-square & 41.164 & 0.004 \\
& ADF - Choi Z-stat & -1.394 & 0.082 \\
\multirow{2}{*}{ AGEN } & ADF - Fisher Chi-square & 86.585 & 0.000 \\
& ADF - Choi Z-stat & -5.164 & 0.000 \\
\multirow{2}{*}{ COLLO } & ADF - Fisher Chi-square & 59.721 & 0.000 \\
& ADF - Choi Z-stat & -4.566 & 0.000 \\
\multirow{2}{*}{ CAP $^{*}$} & ADF- Fisher Chi-square & 85.700 & 0.000 \\
& ADF - Choi Z-stat & -6.070 & 0.000 \\
\hline
\end{tabular}

Note. The total asset growth rate of CAP* is replaced by the first order difference sequence, because of the large number of total assets.

According to the test results, except the ADF - Choi Z-stat test FPRO first-order differential sequence, the test results are significant to reject the unit root hypothesis at the $1 \%$ level, so FPRO, AGEN, COLLO, CAP these four variables are integrated of order one. To ensure that the selected variables are the same order and single integral and then to carry out the cointegration test, we select FPRO, AGEN, COLLO, GURA, CAP* as the explanatory variables of a regression model:

$$
\begin{gathered}
K M V_{i t}=\alpha_{i}+\beta_{1} \Delta F P R O_{i t}+\beta_{2} \Delta A G E N_{i t}+\beta_{3} \Delta C O L L O_{i t}+\beta_{4} G U R A_{i t}+\beta_{5} C A P_{i t}^{*}+\varepsilon_{i t} \\
i=1,2, \cdots, 10 \quad t=1,2, \cdots, 11
\end{gathered}
$$

Among them, $\alpha_{i}$ is for the individual intercept, reflecting the impact of special effects on individual model parameters; $\beta$ is as the parameter of the explanatory variables, and the $I$ variable subscript value in individual time t. $\varepsilon_{i t}$ is a random error term, and it obeys the normal distribution of zero mean and variance. 


\subsection{Cointegration Test}

In this paper, the Kao test is used. This method is based on DF and Chiang, which is promoted by Kao and ADF. The null hypothesis of this method is that there is no cointegration relation, and the residuals of the static panel regression are used to construct the statistics. We construct a Kao test by using the delta FPRO, Delta AGEN, Delta COLLO, GURA, CAP* these five zero order variables and the KMV variable, the test results that the statistic is -2.773 , P value is 0.003 , so we reject the null hypothesis that there exists no cointegration relationship in the 5\% level of significance, and it means that there is a long-term stable equilibrium relationship between Delta FPRO, Delta AGEN, Delta COLLO, GURA, CAP*, and KMV these six variables.

Table 7. Kao inspection result

\begin{tabular}{ccc}
\hline Kao Test & T statistical magnitude & P-value \\
\hline & -2.773 & 0.003 \\
\hline
\end{tabular}

\subsection{Hausman Test}

Hausman test is used to determine the choice of fixed effect model and random effects model. The null hypothesis is that internal estimator (least squares virtual variable (LSDV)) and GLS estimators are consistent, but internal estimator is not effective.

So under the null hypothesis, the gap of absolute value between $\hat{\beta}_{w}$ and $\hat{\beta}_{G L S}$ should not be significant, and should be reduced with the increase of the sample, and gradually converge to zero. However, under the alternative hypothesis, it is not established. Hausman established test statistics as shown in the following type based on the statistical characteristics:

$$
W=\left(\hat{\beta}_{w}-\hat{\beta}_{G L S}\right)^{\prime} \sum_{\beta}^{-1}\left(\hat{\beta}_{w}-\hat{\beta}_{G L S}\right)
$$

The Hausman test statistic gradually follows the chi-square distribution of degrees of freedom.

We use Eviews software to test, the results shown in Table 8 below:

Table 8. Hausman inspection result

\begin{tabular}{cccc}
\hline Test Summary & Chi-Sq. Statistic & Chi-Sq. d.f. & Prob. \\
\hline Cross-section random & 24.444 & 5 & 0.0002 \\
\hline
\end{tabular}

According to the results in the table, Chi-Sq statistics is 24.444 , and $\mathrm{P}$ value is 0.0002 . Therefore, we refuse null hypothesis that fixed effect model and random effect model do not exist systematic differences, but set up fixed effect model.

\subsection{Fixed Effect Variable Intercept Model}

By using eviews8.0 software to estimate the model solution, the estimated results are shown in Table 9.

Table 9. Fixed effect variable intercept model regression results

\begin{tabular}{ccccc}
\hline Variable & Coefficient & Std. Error & t-Statistic & Prob \\
\hline C & 0.0067 & 0.0027 & 2.4890 & 0.0150 \\
$\Delta$ FPRO & $2.01 \mathrm{E}-06$ & $5.30 \mathrm{E}-07$ & 3.7988 & 0.0003 \\
$\Delta$ AGEN & $6.54 \mathrm{E}-09$ & $3.20 \mathrm{E}-09$ & 2.0414 & 0.0447 \\
$\Delta$ COLLO & $-8.39 \mathrm{E}-05$ & 0.0002 & -0.5546 & 0.5808 \\
GUAR & 0.0005 & 0.0001 & 4.2557 & $5.96 \mathrm{E}-05$ \\
CAP* & -0.0244 & 0.0153 & -1.5997 & 0.1139 \\
\hline \multicolumn{2}{r}{ Weighted statistics } \\
\hline R square Adjusted & 0.470 & F-statistic & 4.752 \\
Adjusted & 0.371 & Prob. & 0.000 \\
\hline
\end{tabular}

\subsection{Analysis of Regression Results}

From the $t$ statistic and the p-value in Table 9, we can conclude that the three variables of $\triangle$ FPRO, $\triangle$ AGEN and GUAR reject the original hypothesis at the significance level of 5\%, indicating the increase in the scale of financial products, The three variables of business income growth and guarantee commitment to business income 
have a significant impact on KMV. And $\triangle$ COLLO has no significant effect on KMV, the total asset growth rate has a certain impact on credit risk, but not very significant.

And because the agent commissioned business income can represent the size of the entrusted loan business, the guarantee commitment income can represent the size of the bank acceptance bill business, so we can think that the size of the commissioned loan business, the size of the acceptance bill business, the scale of bank financial products the growth will have a significant impact on the risk of commercial banks. The increase in the size of the trust loan business represented by the corresponding increase in the amount of trusteeship and entrusted business has no significant impact on the risk of commercial banks.

According to the cointegration test, the influence of the shadow banking business on the credit risk of commercial banks is effective in the long run.

From the perspective of various shadow banking business to the risk effect of commercial banks, the scale of financial product growth, the scale of entrusted loan growth, the scale of acceptance bill and the credit risk of commercial banks are positively correlated, the total asset growth rate is negatively correlated with commercial bank credit risk The When the scale of financial products to expand the scale, that is, when the rapid development of financial products business, it will exacerbate the commercial bank's own mismatch problem, and then increase the credit risk of commercial banks; when the increase in the amount of entrusted loans, When the speed of business development is accelerated, the credit conversion of commercial banks is more complicated, so as to increase the credit risk of commercial banks. When the scale of the acceptance bills is expanded, there will be the phenomenon of using the acceptance drafts to disturb the financial order and improve the commercial Bank risk level.

In view of the effect of various shadow banking business on the credit risk of commercial banks, since the description variable of financial products and entrusted loans is the increment of business, the variables used to represent the guarantee commitments are the size of the scale, so the effect cannot be between The specific comparison. When the increase in financial products increased by 100 billion yuan, the probability of default of commercial banks calculated by KMV model will increase by $0.22 \%$; the increase in entrusted loan size will increase by 100 million yuan and the probability of default will increase by $0.00794 \%$; An increase of 100 million yuan, the probability of default increase of $0.047 \%$.

\section{Conclusions and Policy Recommendations}

The regression results by empirical testing, we can conclude that the size of the entrusted loans incremental financial products have a significant impact to the credit risk of commercial banks, but no significant causal relationship with the size of the trust loan. So, we suggest that commercial banks should control the financial product and the increase of the number of the entrusted loans, meanwhile manage share of bank acceptance of draft and proportion. Specific policy recommendations are as follows

\subsection{Financial Products and Entrusted Loans}

According to industry data, these two businesses are mostly capital flows of steel, coal, real estate such excess entity. Such enterprises in order to pursue the development of ultra-speed so the demand for excess funds, resulting in commercial banking products and entrusted loans issued too fast. As a commercial bank, cannot blindly make its funds flowing in these hollow and speculative industries, but should be a comprehensive and prudent examination of capital flows and use, and ultimately ensure that financial products and entrusted loan issue speed can be stable, high quality, Rather than irrationally explosive growth.

\subsection{Acceptance Bill}

Because of its high credit, strong liquidity and low discount rate, the acceptance bill has become one of the important ways of mutual settlement between enterprises, and is conducive to strengthening the social capital financing. However, in our survey, it is found that commercial banks have opened a large number of accounts in the name of their own business, issuing bank acceptance bills, disguised loans or financing, and converting the assets in the table into off-balance sheet assets to evade credit control. In this case, the operating conditions of the drawer and the financial situation has not been strictly reviewed, the flow of funds to monitor the poor, once the source of repayment cannot be guaranteed, commercial banks will be a serious breach of contract. So, it should control the share of the acceptance and the proportion of the table to curb the assets of the table off-balance sheet assets occurred.

\section{References}

Board, F. S. (2011). Shadow banking: Scoping the issues. A Background Note of the Financial Stability Board, 
12. Retrieved from http://www.fsb.org/wp-content/uploads/r_110412a.pdf

Calmès, C., \& Théoret, R. (2011). The rise of shadow banking and the hidden benefits of diversification (No. UQO-DSA-wp042011). Département des sciences administratives, UQO. Received from https://www.researchgate.net/publication/239809560

Gao, L. (2013). Study on the effect of shadow banking on commercial banks in China. Unpublished master dissertation, Shandong University, China. Retrieved from http://cdmd.cnki.com.cn/Article/CDMD-10422-1013220980.htm

Geithner, T. (2010). Testimony before the Financial Crisis Inquiry Commission Causes of the Financial Crisis and the Case for Reform (p. 1). Retrieved from http://www.cftc.gov/PressRoom/SpeechesTestimony/opagensler-48

Guo, C. (2016). Analysis on the characteristics and regulation of shadow banking in Chinese Commercial Banks. Journal of Shandong Institute of Business and Technology. 30(2), 70-73. https://doi.org/10.3969/j.issn.1672-5956.2016.02.011

Han, M. (2009). Research on the effects of monetary policy instruments mainly used in China. Master dissertation, Jiangxi University of Finance and Economics, China. https://doi.org/10.7666/d.y1661555

Instefjord, N. (2005). Risk and hedging: Do credit derivatives increase bank risk?. Journal of Banking \& Finance, 29(2), 333-345. http://dx.doi.org/10.1016/j.jbankfin.2004.05.008

Jiang, S. B. (2016). Research on credit risk of commercial banks based on KMV dynamic default distance. Journal of Finance and Economics. 3(5), 27, 61-65. https://doi.org/10.3969/j.issn.1006-169X.2016.05.012

Mao, Z. S., \& Wang, Y. L. (2012). A study on threshold effect of China's shadow banking and banking system stability. Studies of International Finance. 11, 65-73. Retrieved from http://www.cnki.com.cn/Article/CJFDTotal-GJJR201211009.htm

McCulley, P. (2007). Teton reflections. PIMCO Global Central Bank Focus, 2.

Pozsar, Z., Adrian, T., Ashcraft, A. B., \& Boesky, H. (2010). Shadow banking. https://doi.org/10.2139/ssrn.1645337

\section{Copyrights}

Copyright for this article is retained by the author(s), with first publication rights granted to the journal.

This is an open-access article distributed under the terms and conditions of the Creative Commons Attribution license (http://creativecommons.org/licenses/by/4.0/). 